\title{
Polis
}

Revista Latinoamericana

\section{Prometeo, el discernimiento de los dioses y la ética del sujeto}

Reflexiones sobre un mito fundante de la modernidad

Prométhée, le discernement des dieux et l'éthique du sujet. Réflexions sur un mythe fondateur de la modernité

Prometheus, the judgment of the gods and the ethics of the subject. Reflections on a founding myth of modernity

\section{Franz Hinkelammert}

\section{(QpenEdition \\ Journals}

\section{Edición electrónica}

URL: http://journals.openedition.org/polis/5527

ISSN: 0718-6568

\section{Editor}

Centro de Investigación Sociedad y Politicas Públicas (CISPO)

\section{Edición impresa}

Fecha de publicación: 14 abril 2006

ISSN: 0717-6554

Referencia electrónica

Franz Hinkelammert, « Prometeo, el discernimiento de los dioses y la ética del sujeto », Polis [En línea], 13 | 2006, Publicado el 14 agosto 2012, consultado el 19 abril 2019. URL : http://

journals.openedition.org/polis/5527

Este documento fue generado automáticamente el 19 abril 2019.

(c) Polis 


\section{Prometeo, el discernimiento de los dioses y la ética del sujeto}

Reflexiones sobre un mito fundante de la modernidad

Prométhée, le discernement des dieux et l'éthique du sujet. Réflexions sur un

mythe fondateur de la modernité

Prometheus, the judgment of the gods and the ethics of the subject. Reflections

on a founding myth of modernity

Franz Hinkelammert

\section{El Prometeo del temprano joven Marx y el discernimiento de los dioses}

1 Hay una cita del temprano joven Marx ${ }^{1}$, del prólogo de su tesis doctoral, que considero apropiada para abordar el análisis del complejo de Prometeo: "En cuanto todavía pulsa una gota de sangre en su corazón absolutamente libre y capaz de imponerse al mundo, la filosofía, va a gritar a sus adversarios junto con Epicuro: 'No es ateo aquél que barre con los dioses de la multitud, sino aquél que imputa a los dioses las imaginaciones de la multitud'. La confesión de Prometeo: "En una palabra, odio con toda fuerza a todos y a cualquier dios" es la confesión propia (de la filosofía), su propia sentencia en contra de todos los dioses del cielo y de la tierra, que no reconocen la autoconciencia humana (el ser humano consciente de sí mismo) como la divinidad suprema. Al lado de ella no habrá otro Dios"2

2 En el calendario filosófico, Prometeo ocupa el primer rango entre los santos y los mártires"3. Se trata, de hecho, de un Prometeo excepcional y en cierto sentido es la cima de todos los Prometeos. Marx se refiere tanto al Epicuro como al Prometeo griegos. El Epicuro griego relativiza el mundo de los dioses y tiene conciencia de que éstos se crean según la imaginación humana. En otro texto dice algo así como: "Si los caballos tuvieran dioses, éstos tendrían la forma de caballos". Pero, Epicuro no enfrenta el mundo de los 
dioses, sino que los deja de lado sin discutir si existen o no, o cuál de ellos sería verdadero. Tampoco pone en cuestión el hecho de que los caballos no tienen dioses y no pueden tenerlos. Deja de lado a los dioses para concentrarse en una vida buena, que es vida con los amigos, y no avanza más allá de eso.

El Prometeo griego, que Marx presenta, es un dios-titán (hijo de un titán y una diosa). Es un dios inmortal, que tiene acceso a los dioses del olimpo. Sin embargo, odia a todos los dioses, y ese odio es un tipo de reconocimiento. No niega la existencia de los dioses. Este Prometeo no es un ser humano, sin embargo aparece en dramas como el de Esquilo, donde los seres humanos son los observadores. Estos miran espantados. Les ha dado el fuego a los hombres como una dádiva del cielo y ahora están frente a él admirándolo y atemorizados. Entienden su odio a los dioses del Olimpo, pero no lo comparten. Perciben un sacrilegio, pero no pueden condenarlo y no lo hacen. Pero, todo ocurre en el otro mundo de los cielos, frente a un público humano.

4 Ya en la antigua Grecia encontramos muchas versiones de la historia de Prometeo. Aparece como el dios-titán, que forma a los hombres del barro, consiguiendo el fuego divino para inculcarles el alma. Este relato forma parte del mito de la Edad de Oro, en la cual hay solamente hombres, y los niños nacen de la tierra. Es una sociedad tranquila y sin inquietud. Zeus manda la primera mujer, que es Pandora. Ella trae la desgracia a este mundo paradisíaco. Los mitos griegos hablan de la mujer como la "desgracia hermosa".

Este Prometeo roba del cielo de los dioses el fuego y lo regala como dádiva a los hombres. Con el fuego empieza el desarrollo civilizatorio, por eso, es venerado como el dios de la producción, de la artesanía y del desarrollo civilizatorio en general. Por robar el fuego, Zeus castiga a Prometeo. Lo manda a encadenar en el Cáucaso y le manda un águila, que le devora el hígado, que se renueva todos los días, y el águila vuelve a devorarlo diariamente. Sufre este castigo durante treinta mil años. En la versión más conocida, Heracles, finalmente, lo libera. Mata al águila y rompe las cadenas de Prometeo. Zeus lo acepta bajo una condición: Prometeo tiene ahora que llevar para siempre un anillo forjado del hierro de la cadena. Transforma el castigo sangriento en un castigo simbólico.

Este mito de Prometeo proporciona los elementos para la imaginación prometeica a partir del Renacimiento. Todos los mitos construidos desde el del Prometeo griego tienen un rasgo común, que los distingue a todos del mito griego: en ellos Prometeo es visto como un hombre rebelde que se levanta frente a los dioses, deja de ser un dios y se transforma en hombre. El mito griego sirve más bien como una cantera para la reconstrucción mítica de una rebeldía y emancipación humanas, la cual es realizada por la sociedad moderna a partir del Renacimiento. En este horizonte se inscribe también el Prometeo imaginado por Marx.

7 Ahora bien, cuando el Prometeo de Marx habla, por su boca habla la filosofía. Esta asume la posición de Prometeo, pero al hacerla suya no expresa odio, sino una sentencia que Marx hace suya: "en contra de todos los dioses del cielo y de la tierra, que no reconocen la autoconciencia humana (en traducción literal: el ser humano conciente de sí mismo) como la divinidad suprema. Al lado de ella no habrá otro Dios".

8 Lo que Marx hace, en nombre de Prometeo, es un discernimiento de los dioses. Ninguna de las anteriores figuras de Prometeo la ha hecho. Marx distingue entre dioses falsos y dioses verdaderos. Los falsos son aquellos que no reconocen la autoconciencia humana como divinidad suprema, y los dioses verdaderos sí la reconocen. Este discernimiento no tiene nada de griego. Es el conflicto de la tradición judía entre los ídolos y Dios. Al 
contrario; concebir un Dios para el cual el ser humano es la divinidad suprema, sería hibris en la tradición griega.

Se trata de un Prometeo profundamente transformado, que incluso da un salto respecto a la tradición prometeica anterior. Hay un famoso poema de Goethe que me ha fascinado desde joven y que aprendí de memoria, que todavía conserva aquella figura diferente. Empieza así: "Cubre tu cielo, Zeus/ con vapor de nubes/ y manifiesta tu poder,/ como un niño que descabeza cardos,/ sobre encinas y montañas./ Pero, no te atrevas con mi tierra/ y mi cabaña,/ que tú no has construido,/ ni con mi hogar/ cuya llama me envidias./ No conozco bajo el sol nada más pobre que vosotros, los dioses". Y termina diciendo: "Aquí me mantengo firme,/ modelando hombres a mi imagen,/ una estirpe que sea como yo,/ que sufra, llore,/ disfrute y se alegre sin estar pendiente de ti,/ como hago yo"'.

10 En este poema está el ser humano que se alza frente a Dios/Zeus, pero no hay discernimiento. También este Prometeo es ya un ser humano, pero, no tiene ningún criterio para decir quién es este ser. Modela hombres según su imagen, pero su imagen no es más que modelarlos. En el Prometeo de Goethe no se encuentra lo que aparece en la cita de Marx: la autoconciencia humana (el ser humano conciente de sí mismo) como criterio que proporciona la imagen, según la cual hay que formar a los seres humanos.

11 Este criterio de discernimiento está directamente vinculado con el hecho de que la sentencia del Prometeo de Marx se refiere a los dioses del cielo y de la tierra. Ningún Prometeo anterior enfrenta los dioses de la tierra. Pero, el discernimiento se hace en la tierra, para pasarlo al cielo. Por eso, la sentencia sobre los dioses de la tierra es la decisiva, tanto que marca un hito en el desarrollo de las imágenes de Prometeo. Marx denuncia ahora al mercado y al Estado como dioses falsos, en cuanto no aceptan al ser humano como divinidad suprema. Ahora, definitivamente, la lucha de los dioses se convierte en una lucha en la tierra.

Pocos años después, Marx prosigue esta reflexión, y a la vez la modifica. El prólogo citado anteriormente es de 1841; en la Introducción a la crítica de la Filosofía del Derecho de Hegel, de 1844, escribe: "La crítica de la religión desemboca en la doctrina de que el hombre es la esencia suprema para el hombre y, por consiguiente, en el imperativo categórico de echar por tierra todas las relaciones en que el hombre sea un ser humillado, sojuzgado, abandonado y despreciable" 5 . Como puede verse, ya no se refiere a la autoconciencia como suprema divinidad, sino habla ahora del "hombre como la suprema esencia para el hombre". La reflexión, por supuesto, es la misma, pero han cambiado palabras y conceptos. De esta suprema esencia para el hombre deriva ahora su imperativo categórico de echar por tierra todas las relaciones en que el hombre sea un ser humillado, sojuzgado, abandonado y despreciable.

13 Esta esencia suprema no es una esencia metafísica, en el sentido de la metafísica anterior. Sin embargo, es una exigencia, es el llamado a una transformación, que desemboca en una ética, que nace del ser humano mismo en cuanto se quiere realizar como tal. Se trata de una autorrealización en cuanto sujeto humano. Pero, es una autorrealización que echa por tierra todas las relaciones en que el hombre sea un ser humillado, sojuzgado, abandonado y despreciable. Es notable la diferencia con el Prometeo de Goethe, cuya autorrealización no es más que la afirmación de sí mismo y de su poder (su ser como homo faber). Sin embargo, el orgullo prometeico es el mismo en los dos casos; por eso el poema de Goethe sigue siendo tan fascinante. 

1841. En su tesis de doctorado, Marx habla todavía de un posible Dios, para el cual la autoconciencia humana es la divinidad suprema, desde 1844 deja de hacerlo. El cambio es comprensible y se refleja en las ulteriores posturas de Marx frente a la religión. Si el ser humano es la divinidad suprema, ¿para qué, entonces, un Dios? Marx concluye que ahora sobra la referencia a Dios, el cual pasa a ser visto como el ser humano que echa por tierra todas las relaciones en que el hombre sea un ser humillado, sojuzgado, abandonado y despreciable. Por eso, posteriormente va a concluir: no hace falta abolir la religión, sino la religión morirá en cuanto el ser humano se toma a sí mismo como esencia suprema. No sigue concibiendo un Dios que tenga esta esencia humana suprema como divinidad suprema.

Goethe el ser humano es la divinidad suprema. Por consiguiente, tampoco concibe un Dios que tenga el ser humano como divinidad suprema. Pero, se trata de dos formulaciones contrarias: en Goethe el ser humano es divinidad suprema en cuanto homo faber; en Marx lo es en cuanto sujeto humano concreto que se libera. En cuanto homo faber es dominador; en cuanto sujeto es liberador.

Posteriormente Marx transforma esta, su crítica a la religión, en un método de análisis. En efecto, es mucho más fácil encontrar, mediante el análisis, el núcleo terrenal de las imágenes nebulosas de la religión que proceder al revés, partiendo de las condiciones de la vida real en cada época remontarse a sus formas divinizadas. Este último método es el único que puede considerarse como el método materialista y por tanto científico"6.

Se trata ahora de un análisis de las divinizaciones a partir de la vida real. Para mí, es ciertamente el método adecuado en el cual siempre me he inspirado para analizar todo este mundo mítico. Permite analizar los dioses y discernirlos. Se trata de algo para lo cual Marx esbozó todo un programa de investigación, que lamentablemente no ha sido atendido, ni proseguido suficientemente en la tradición marxista. Es un método que permite entender, criticar y evaluar. Por supuesto hace falta analizar de esta manera los dioses de Bush, de Reagan o de Hitler, y su enorme funcionalidad en la política. Pero, igualmente permite analizar los diversos ateísmos y discernirlos. Eso vale igualmente para el ateísmo estalinista, que de ninguna manera viene de Marx, sino de la vida real del socialismo soviético y hay que analizarlo como tal. Este ateismo es también una forma divina de la vida real. Por otro lado, hay ateísmos como el de Ernst Bloch o el de Erich Fromm, que están muy cerca del de Marx, que es realmente un humanismo.

esto mismo vale para el análisis de los diversos Prometeos: todos ellos son producto de la vida real y elaboran míticamente sus formas divinas correspondientes. Sociedades y seres humanos reflexionan sobre sí mismos en medio y por medio de sus formas divinas. Por eso, la historia de las formas históricamente dadas de Prometeo es a la vez la historia real. Las mismas épocas históricas y los polos de conflicto en cada una de estas épocas, llevan a la construcción de formas de Prometeo diferentes y correspondientes. Lo que es cada época histórica se puede leer en las imaginaciones prometeicas que produce. Creo, que Luri Medrano deja de lado este aspecto.

El referido método tiene como condición prescindir de la pregunta de si Dios existe o no. Es una pregunta que no tiene mucho que hacer aquí. Es como la pregunta por el koan mude la tradición budista. Se trata de una pregunta, frente a la cual tanto el "sí" como el "no" son falsos. Contestar a la pregunta de si existe Dios con el sí, es falso, pero contestar 
con el no es igualmente falso. En este sentido Engels es muy miope en relación a Marx, cuando dictamina que: "La naturaleza existe independientemente de toda filosofía; es la base sobre la que crecieron y se desarrollaron los hombres, que son también, de suyo, productos naturales; fuera de la naturaleza y de los hombres, no existe nada, y los seres superiores que nuestra imaginación religiosa ha forjado no son más que otros tantos reflejos fantásticos de nuestro propio ser"7.

Engels no va más allá de Feuerbach, mientras Marx realizó un salto. Lo que dice Engels, no tiene nada que ver con la crítica de la religión de Marx; más bien es simple metafísica. El marxismo soviético asumió esta línea, aunque por razones propias.

\section{El discernimiento de los dioses en la tradición cristiana}

21 Ahora bien, me propuse hacer algunas pruebas con el primer texto de Marx. Tomé la parte central y sustituí la palabra autoconciencia por “dignidad humana”. Resultó la frase siguiente: "sentencia en contra de todos los dioses del cielo y de la tierra, que no reconocen la dignidad humana como la divinidad suprema. Al lado de ella no habrá otro Dios". Sin mencionar al autor, lo presenté en grupos muy cercanos a la teología de liberación y les pregunté cuál creían que podía ser el sentido de la frase. Siempre concluyeron que se trataba de un texto de teología de liberación. Esperaba esta respuesta y efectivamente se dio. Por supuesto, se mostraron sorprendidos cuando les revelé su autor.

La razón de esta reacción no es difícil de encontrar. El discernimiento de los dioses está en los orígenes de la propia teología de liberación. Esta nunca discutió como un problema la alternativa ateísmo-teísmo, sino siempre el de idolatría-fe, y siempre vinculó la idolatría con los dioses de la tierra. Por eso, en esta corriente hay tantos títulos de artículos o libros con la expresión "idolatría del mercado". Los dioses de la tierra son considerados por la teología de la liberación como dioses falsos. Marx está en esta misma tradición, cuyas raíces son tanto judías como cristianas, pero no tiene raíces griegas. Así el dios Mamón es un dios en la tierra, pero es un ídolo para la tradición cristiana. Esta posición es especialmente destacada en Pablo Richard ${ }^{8}$ y Hugo Assmann?.

Sin embargo, hay otra razón mucho más profunda, que creo necesario mencionar para entender la propia historia de los Prometeos. El arzobispo Romero, que fue asesinado por los militares salvadoreños, recurría muy frecuentemente a las siguientes palabras de San Ireneo de Lyon, que vivió en el siglo II d.C.: "Gloria Dei, vivens homo; vita autem hominis visio Dei. (La gloria de Dios es la vida del ser humano; la vida del ser humano, sin embargo, es la visión de Dios)." Romero especificó la afirmación de Ireneo también en la siguiente forma: "Gloria Dei, vivens pauper (La gloria de Dios es que el pobre viva)".

Estas citas se hicieron famosas en América Latina. Está claro que a quienes asumieron la concepción expresada en ellas por Romero no puede sorprenderles que se hable de un Dios para el cual la dignidad humana es la divinidad suprema, como lo hace el joven Marx en su tesis de doctorado. Ireneo establece un círculo: de una parte, la gloria de Dios es la vida humana; de otra, la vida humana determina la imagen de Dios, es como el marco categorial dentro del cual se forma la imagen de Dios. Con el sentido universal que le otorga Ireneo, la expresión llega a ser idéntica a la de Marx. No creo que Romero haya tenido conciencia de eso, pero hace comprensible que los estudiantes de teología a los que 
presenté la cita de Marx, sin revelar el nombre del autor, hayan creído que pertenecía a un teólogo de liberación.

Creo que esta referencia de Romero a Ireneo de Lyon nos revela algo que debemos destacar si queremos entender la historia de Prometeo desde el Renacimiento. Nos remite a una transformación profunda de toda la cultura antigua, acaecida en los primeros siglos de nuestra era, que impulsa toda la historia posterior. Aunque la consideramos normalmente como una simple creencia "religiosa", es en realidad algo que divide la historia, y sin lo cual no podemos comprender el período que viene posteriormente. En términos "religiosos" irrumpe con el cristianismo: Dios se hizo un ser humano, el ser humano se hizo Dios. De hecho, lo que irrumpe es una tradición judía anterior, que es condensada en el cristianismo de una manera específica y que orienta, en una dirección nueva, toda la cultura greco-romana. Es como una revolución copernicana, mucho antes de Copérnico: el mundo de los dioses baja a la tierra y los seres humanos asumen la vida de los dioses. Dios llega a ser la otra cara de la humanidad.

Esta transformación, por supuesto, tiene antecedentes tanto en la tradición judía como en la griega, pero no son más que antecedentes. Ahora irrumpe la convicción de que la vida humana debe asumir la vida de los dioses o de Dios. Una frase como la de Ireneo: Gloria Dei vivens homo, es inimaginable antes de esta irrupción. Toda relación con el mundo de los dioses se ha trastocado. Hay acceso a Dios, y Dios es transformado en el destino humano. En Ireneo aparece eso en forma radical. No es solamente este Gloria Dei vivens homo, sino que ahora la creación de todo el universo tiene su sentido en la creación del ser humano, y la historia humana es transformada en una escalera desde la tierra al cielo, un camino que lleva a la identidad del ser humano y Dios. El ser humano se transforma en el centro del universo, de la historia y de Dios.

Con eso despierta la conciencia de la dimensión del sujeto frente a todas las limitaciones externas que rigen sobre el ser humano. En los propios orígenes del cristianismo encontramos este sujeto. Jesús en el evangelio de Juan dice: "Yo he dicho: Dioses sois" ( Juan 10, 33). Cada uno ahora es declarado Dios, Jesús lo dice citando el salmo 82. En una lectura literal este salmo no expresa lo que Jesús le hace decir quien le da una interpretación nueva e incluso lo extrae de su contexto. Sin embargo, al hacerlo, esta interpretación es posible. Con ella despierta un sujeto, que anteriormente más bien estaba dormido o enterrado. San Pablo saca una conclusión. Según él, ya no hay "judío ni griego; ni esclavo ni libre; ni hombre ni mujer" (Gal., 3, 28). El hecho de que se trata de un sujeto corporal y necesitado lo expresa la fe en la resurrección primero de Jesús y posteriormente de todos. Se trata del germen del sujeto moderno, aunque todavía envuelto en un manto religioso. A partir de eso se entiende la expresión de Ireneo de Lyon: Gloria Dei vivens homo. Dios mismo es transformado en colaborador y cómplice de este proyecto de sujeto. He aquí la ruptura.

Luri Medrano cita a un epicúreo, Diógenes de Oenoanda (Siglo II-III A. D.), que expresa igualmente este cambio: "Cuando nadie domine, entonces realmente la vida de los dioses se transformará en vida humana. En todas partes reinará la justicia y el mutuo aprecio y no habrá necesidad ni de murallas ni de leyes, pues todo lo necesario viene de la tierra y todos labraremos y cultivaremos y cuidaremos del ganado y encauzaremos ríos, y en los ratos libres podremos dedicarnos al estudio de la filosofía" ${ }^{10}$.

29 La vida de los dioses se transformará en vida humana, no habrá dominación ni leyes, pero la justicia reinará. Luri Medrano hace el siguiente comentario: "En este contexto cultural el epicureismo esboza un proyecto de una inmensa repercusión histórica. Se trata de 
transferir la Edad de Oro de un pasado mítico a un futuro posible. Resaltemos que este intento de sustituir el tiempo en el que Crono pastoreaba a los hombres por el de unos hombres cuidando de la tierra y de los ganados, en una sociedad solidaria y amante de la filosofía, no se presenta en este texto como un retorno a un idílico pasado, sino como una aspiración racional y, por tanto, irrenunciable a ho bíos asphalés, es decir, a una vida segura que sea, al mismo tiempo, una vida natural"11.

Lo que dice Ireneo de Lyon es una simple variación del texto de Diógenes de Oenoanda,; sin embargo, su postura es mucho más radical, pues pone el ser humano en el centro del universo, de la historia y del mismo Dios. Luri Medrano considera esto como una herencia del epicureismo, pero lo que ha ocurrido es una ruptura de toda la cultura anterior, que aparece de una u otra forma en todo el pensamiento de este tiempo y, por tanto, también en el epicureismo. Aparece, con variaciones, también en el neoplatonismo, que se mueve muy cerca de la mística posterior.

31 Ciertamente, para Luri Medrano se trata "de transferir la Edad de Oro de un pasado mítico a un futuro posible". Pero eso ya lo había hecho el Apocalipsis de San Juan, que abandonó el paraíso para ir a la nueva tierra, que es un futuro sin árbol prohibido, en el cual reinará la justicia y en el cual la vida de Dios se transfiere a la vida humana. La cita de Diógenes de Oenoanda, sin embargo, tiene un evidente y especial interés. Tiene un parecido sorprendente con un texto famoso de Marx.

"En efecto, a partir del momento en que comienza a dividirse el trabajo, cada cual se mueve en un determinado círculo exclusivo de actividades, que le es impuesto y del que no puede salirse; el hombre es cazador, pescador, pastor o crítico, y no tiene más remedio que seguirlo siendo, si no quiere verse privado de los medios de vida. En la sociedad comunista, cada individuo no tiene acotado un círculo exclusivo de actividades, sino que puede desarrollar sus aptitudes en la rama que mejor le parezca, la sociedad se encarga de regular la producción general, con lo que hace cabalmente posible que yo pueda dedicarme hoy a esto y mañana a aquello, que pueda por la mañana cazar, por la tarde pescar y por la noche apacentar el ganado, y después de comer, si me place, dedicarme a criticar, sin necesidad de ser exclusivamente cazador, pescador, pastor o crítico, según los casos"12.

Sin embargo, parece imposible que Marx haya conocido el texto de Diógenes de Oenoanda, que fue publicado, por primera vez, sólo en el año 1974, después de haber sido encontrado en una excavación arqueológica. Sin embargo, de hecho hay una recuperación de algo, que ha estado enterrado o marginado en toda una historia anterior. Pero, se trata de una dimensión humana de la historia, que ha aparecido en los primeros siglos y que ha impregnado, aunque bajo la forma de reformulaciones, falsificaciones e inversiones, toda la historia posterior.

\section{Cuando Dios se hace ser humano, el ser humano se hace Dios}

34 Si ahora queremos entender por qué la figura de Prometeo aparece con tanta fuerza a partir del Renacimiento, tenemos que preguntarnos por el carácter de la gran ruptura cultural de los primeros siglos. Llama la atención que este Prometeo de la modernidad esté completamente impregnado por esta ruptura. El Prometeo griego es un dios-titán, que es inmortal y tiene acceso al Olimpo de los dioses griegos. En cambio, El Prometeo que 
surge a partir del Renacimiento es un hombre, que asume como hombre el ser Prometeo. Eso ya es obvio en el drama de Calderón de la Barca, al cual Luri Medrano con razón da una importancia clave. El Prometeo de este drama es un hombre nacido en el Cáucaso, que se hace educador de su pueblo. El dios-titán Prometeo se hizo hombre, para que los hombres se hagan Prometeo. Obviamente, se trata de un Prometeo post-cristiano, y en modo alguno implica un retorno al Prometeo griego. Esto sucede con todos las figuras de los Prometeos posteriores. El Prometeo griego da la palabra clave, pero no mucho más. Es santo y seña, un password. Se continúa usando elementos de los relatos griegos sobre él, pero su significado se ha transformado completamente.

Pero, ¿por qué aparece el Prometeo moderno, post-cristiano? Creo que hay que hacerse esta pregunta. No hay duda que se trata de una respuesta a una cultura cristiana, que fue surgiendo en un imperio que está entrando en declive. Entonces, el Dios que se hace ser humano para que el ser humano se haga Dios, es sustituido por el Prometeo que se hace hombre para que el hombre se haga Prometeo. Haciéndose Prometeo se hace un titán y sale de viaje en un barco con destino al infinito que se llama Titanic. Pero, resulta claro que no puede haber cambiado solamente una palabra; hay un cambio cultural, dentro del cual se entiende el cambio de significado de las palabras.

Habría que preguntarse, ¿qué ha ocurrido en el cristianismo con el Dios que se hizo ser humano para que el ser humano se haga Dios? ¿Qué ha ocurrido en el cristianismo de la etapa anterior al surgimiento del Prometeo del Renacimiento? ¿Qué ha ocurrido con la expresión secularizada de la ortodoxia cristiana? El cristianismo de la ortodoxia se mantiene, por supuesto, en el espacio creado por la ruptura de los primeros siglos: Dios se hizo un ser humano, por tanto, el ser humano se hace Dios. Eso se ha transformado en una categoría del pensamiento. Pero esta ortodoxia invierte esta relación.

Para hacer ver esta inversión, puedo mencionar la reinterpretación que hace el Papa Juan Pablo II respecto a Ireneo y su concepción de la Gloria Dei vivens homo. Se trata, de la posición que asume, solapadamente, Juan Pablo II frente al Arzobispo Romero que contiene su condena a éste, también subrepticia. Dice Juan Pablo II: "Entonces se puede repetir verdaderamente que la "gloria de Dios es el hombre viviente, pero la vida del hombre es la visión de Dios": el hombre, viviendo una vida divina, es la gloria de Dios, y el Espíritu Santo es el dispensador oculto de esta vida y de esta gloria" ${ }^{13}$.

Para Ireneo la vida humana es la gloria de Dios, y lo es de por sí y en un sentido universal, pero Juan Pablo II no acepta esto. Para él, el hombre es gloria de Dios, solamente, en cuanto vive una vida divina, y el Papa, o cualquier autoridad, es quien determina qué es una vida divina. Si no vive dicha vida, su vida no es gloria de Dios. Por tanto, hay un Espíritu Santo, que dispensa esta vida, que es gloria de Dios, sólo a aquellos que lo merecen. Lo hace ocultamente, es decir, no se puede ver en la vida real, por tanto, no se refiere a la vida real y concreta. Esta reinterpretación implica una condena de Romero, y no tengo dudas de que Juan Pablo II quiere decir precisamente eso. Según él, Romero tiene una fe falsa y es hereje, inclusive es un rebelde frente a Dios. Y esto es a la vez su juicio sobre la teología de liberación.

Esta crítica solapada a Romero es la misma que también Agustín de Hipona realiza, en el siglo V, a las tesis del tipo de la de Ireneo. Dice: "Veremos que Él es Dios, que es lo que quisimos y pretendimos ser nosotros cuando caímos de su gracia, dando oídos y crédito al engañador que nos dijo: "seréis como Dios" y apartándonos del verdadero Dios, por cuya voluntad y gracia fuéramos dioses por participación, y no por rebelión. Porque ¿qué 
hicimos sin Él, sino deshacernos, enojándole? Por Él, creados y restaurados con mayor gracia, permaneceremos descansando para siempre, viendo cómo Él es Dios, de quien estaremos llenos cuando Él será todas las cosas en todos" ${ }^{14}$.

Agustín no duda de que los seres humanos lleguen a ser dioses, pero no por rebelión, sino por participación. Agustín recupera el sometimiento y lo presenta como divinización, por la vía de la obediencia. Es claro que está hablando el teólogo del imperio cristiano. Todo imperio busca la divinización por sometimiento y jamás por rebelión. Sin embargo, eso elimina algo importante: elimina la crítica de los ídolos. Dios ya no es la vida humana, sino la vida de un sistema dominador. Es el sistema de la cristiandad. Lo que este sistema denuncia como rebelión, es, precisamente, la crítica de la idolatría de los dioses en la tierra, a los cuales este sistema de dominación pertenece.

41 Esta breve cita de Agustín puede iluminar qué es y cómo se entiende el sistema de dominación del imperio cristiano. El sujeto de los orígenes es reprimido y en su lugar se erige el imperio cristiano, que sirve a Dios y que es ahora el centro del universo y de la historia. Pero, es también el centro de Dios, porque Dios tiene su gloria en su expansión. Es el sujeto sustitutivo. Lo que era antes el sujeto, es ahora el servidor del imperio, que se hace Dios por participación en el imperio. La iglesia es ahora la instancia que interpreta las acciones del imperio y las orienta para que sirvan a la gloria de Dios. El imperio pretende ser total., no domina la tierra y menos el universo, y tampoco domina la historia. Pero, su proyecto es el de dominación, que identifica con la gloria de Dios, el cual no tiene otra gloria. La divinización del imperio dirige la divinización del ser humano. Llega a ser Dios si cumple con sus leyes y órdenes. La rebelión es el pecado del orgullo. Sin embargo, toda crítica de esta idolatría del dominio aparece como rebelión. Este es un Dios en la tierra que pretende ser el único y que es extremamente celoso y lo celebra condenando a las hogueras a todos los que se resisten.

La conquista de la tierra forma parte de la conquista universal de este imperio de la cristiandad, porque toda la tierra es de Dios y el imperio es su herramienta. Pero, sigue siendo conquista en nombre de la cristiandad y para convertir al cristianismo. Por supuesto, prefieren conquistar para Dios aquellas tierras donde hay más riqueza para robar. Primero, mediante las cruzadas, se invadió el Medio Oriente, que era mucho más rico que Europa. Después fue América, y la conquista y conversión al cristianismo siguió siendo el modelo de las conquistas española y portuguesa. Dios como recompensa concede como botín las riquezas de los países conquistados. Cortés conquista México en nombre de Dios y el rey. Las riquezas que roba son su recompensa. Dios y el rey no son pretextos. No se trata en realidad de riquezas que tienen a Dios como pretexto. Se trata realmente de Dios, puesto que El es la otra cara de estas riquezas. Cortés es un beato piadoso. Ocurrió con la conquista cristiana lo que hoy sucede con las conquistas realizadas, actualmente, por Estados Unidos. Llevan la libertad, y conquistan para eso; preferentemente llevan la libertad a países con petróleo. Pero, del pillaje de estos países extrae un botín que lo recompensa por el esfuerzo de llevar la libertad. Esta no es el pretexto de algo real que sería el pillaje del petróleo. Al contrario, se trata de libertad, y ésta es la otra cara del pillaje. Por eso son tan beatos y piadosos con la libertad. Es el pillaje practicado como virtud. Probablemente, sin esta construcción no serían capaces de cometer tantos crímenes. Eso tranquiliza la conciencia moral, tan desarrollada en nuestra civilización.

Las conquistas españolas y portuguesas fueron las últimas realizadas en nombre de la cristiandad. Los colonialismos posteriores operan en nombre de la libertad y lo siguen 
haciendo hasta hoy. Son prometeicos: Prometeo hecho hombre se dedica a educar la humanidad entera. Va a civilizar la tierra y lleva la carga del hombre blanco. Y siempre habrá buenas recompensas. Por tanto, desde el interior del sistema de cristiandad se desarrolla la modernidad, que revierte sobre éste y lo rompe. Entonces, regresa el sujeto reprimido desde los inicios. La historia del imperio cristiano está impregnada por los regresos de este sujeto, aunque siempre de nuevo se lo vuelve a reprimir y enterrar, pero resucita. Con el Renacimiento aparece un gran retorno de este sujeto, sin embargo se produce, también, un nuevo entierro. Me parece que este retorno usa como uno de sus ropajes el de Prometeo.

Desde el Renacimiento surge, en el interior de este sistema, un humanismo universal, que excede cualquier forma religiosa. No desaparece la religión, sino que es transformada en un comentario religioso referido a este humanismo universal humano. No constituye la esencia de este humanismo renacentista, sino lo acompaña o bien no lo hace. Según San Pablo, con el advenimiento del cristianismo ya no había "ni judío ni griego; ni esclavo ni libre; ni hombre ni mujer" (Gal., 3, 28). Es así como nace el sujeto con el cristianismo. El humanismo universal del Renacimiento lo rebasa: el sujeto no sólo no es "ni judío ni griego; ni esclavo ni libre; ni hombre ni mujer", sino también "ni cristiano ni ateo". Dicho humanismo está fundado en el ser humano mismo, con anterioridad de su ser cristiano o ateo, budista o islámico. Todos los conflictos posteriores hasta hoy giran alrededor de este humanismo universal, en relación al cual las confesiones religiosas o ateas adquieren carácter secundario ${ }^{15}$.

\section{Cuando Prometeo se convierte en ser humano, éste se hace Prometeo}

Con la Ilustración del siglo XVIII, este sujeto se transforma en el individuo burgués. El humanismo burgués es tan universal, aunque al comienzo lo sea sólo como pretensión, como el humanismo del Renacimiento. Surge ahora el universalismo del mercado basado en la concepción del individuo universal. También para este universalismo del individuo vale lo que San Pablo había dicho: "ni judío ni griego; ni esclavo ni libre; ni hombre ni mujer", y con el añadido "ni cristiano, ni ateo". Pero, el sujeto humano concreto y necesitado desaparece y es reprimido. El individuo es propietario, no es sujeto, pero es tan universal como lo era antes el sujeto.

Este universalismo del individuo conserva la misma perspectiva infinita que adquirió en su origen en el cristianismo. El universalismo del individuo y, por tanto, del mercado, es centro del universo, centro de la historia y centro de Dios. Es conquistador, y conquista la tierra y el universo, la historia y el cielo. Por eso, se envuelve en el mito del progreso. Incluye estas tres conquistas hasta lo infinito, y determina con eso el espacio de todos los sentidos posibles y admisibles de la vida humana. Lo pueden llenar las religiones si quieren, pero no lo determinan. Además, muchas veces las usa o abusa de ellas, pero sólo para servirse de las mismas.

Este universalismo no es necesariamente un humanismo que se limite al mito del progreso. Este mito ha sufrido muchas grietas en los últimos cien años y hay una amplia negación de este humanismo. Nietzsche niega que en el proceso histórico haya una tendencia ascendente hacia alguna meta final infinita, y la sustituye por el mito del eterno retorno; y a la vez se lanza en contra de este humanismo. Pero, incluso, a su pesar, 
no puede salir de este universalismo, y hasta lamenta no poder escapar de éste. "Retorna eternamente el hombre del que estás hastiado, el hombre pequeño'. Así hablaba mi tristeza entre bostezo y bostezo, arrastrando los pies, sin poder dormirse. ‘Ay, el hombre retorna eternamente! ¡El hombre pequeño retorna eternamente!'. Cierta vez había visto yo desnudos al hombre más grande y al más pequeño: demasiado parecidos el uno al otro -¡demasiado humano aún el más grande! Demasiado pequeño aún el más grande! -, he aquí mi hastío del hombre. ¡Y retorno eterno aún del más pequeño! -, he aquí mi hastío de toda existencia. Bien sabemos lo que enseñas: que todas las cosas retornan eternamente y nosotros junto con ellas; $y$ que hemos existido ya eternas veces, $y$ todas las cosas junto con nosotros"16. Esto desemboca en algo así como el reverso simétrico del paradigma del misántropo: detesto a todos los humanos por igual, independiente de su clase, su género, su raza y su cultura. La misma negación del universalismo resulta en un universalismo al revés; la negación de la igualdad humana resulta en una igualdad al revés.

En síntesis, el universalismo humanista del Renacimiento implica una profunda ruptura con la Edad Media y el cristianismo universal. Pero, es visible que el sujeto a partir del cual es pensado este universalismo, y con el cual se identifica, no es el sujeto griego ni romano. Es resultado del propio desarrollo del cristianismo y es el efecto no-intencional del desarrollo de la cristiandad imperial anterior. La ruptura no puede hacer desaparecer la continuidad del nuevo sujeto que nació con el cristianismo. Sin embargo, el cristianismo es algo como una escalera necesaria para llegar a este universalismo, pero una vez llegado, la escalera sobra y pierde su importancia crucial; inclusive se la puede botar.

Con esta ruptura reaparece el mito de Prometeo, este Prometeo que se ha hecho hombre para que el hombre sea Prometeo. Se necesita un mito, pero los mitos cristianos ahora confundirían. En cambio, Grecia está suficientemente lejos como para proporcionar las imágenes necesarias sin limitar la imaginación presente. Los grandes pensadores de la cristiandad medieval tienen una relación mucho más directa con el pensamiento griego que los pensadores del Renacimiento. Agustín parte del neoplatonismo y Tomás de Aquino de Aristóteles. Ciertamente los transforman, pero mantienen una gran dependencia con ellos. En el Renacimiento eso no ocurre, excepto en las artes. También el pensamiento griego es antecedente importante y hasta decisivo, pero no es más que un antecedente. Y cuando aparece la aspiración democrática, ésta tiene una dimensión radicalmente distinta de las democracias griegas y romanas, a pesar de que los actores algunas veces -como los jacobinos- se visten con togas romanas.

Sin embargo, míticamente, el Renacimiento se expresa con imágenes griegas y romanas. Da algo como un efecto de Verfremdung (distanciamiento) como el descrito por Brech, dada la semejanza y cercanía tan grande con el cristianismo anterior. Además, efectivamente el plano de la acción ha cambiado. Todo se desarrolla ahora desde relaciones interpersonales, dadas y previas a todas las elaboraciones teóricas, y no desde la autoridad política o religiosa. Por estas y por muchas otras razones se necesita un imaginario diferente. Por ello, en las biografías de Prometeo, a partir del Renacimiento, aparece la propia historia de la modernidad: su mito del progreso, su titanismo y sus crisis. Sin embargo, para un griego todas estas imágenes serían irreconocibles. El nuevo mundo no es solamente América, sino todo lo que se hace y se piensa.

51 Por eso, Prometeo resulta el gran mito de la modernidad. Desde el siglo XVII-XVIII, éste es el mito de la sociedad burguesa. Su grandeza, su prepotencia y sus crisis aparecen en éste. 
En los Golem, los Frankenstein y después en el hundimiento del Titanic se muestran hasta sus fracasos. En Fausto, una obra prometeica también, se evidencia el mismo fracaso. La filosofía de Nietzsche es testigo, igualmente, de este fracaso. Y desde el siglo XX Prometeo es cada vez más una figura banal, mientras el grandioso mito del progreso ha sido burocratizado y vulgarizado en las tasas de crecimiento impulsadas por el FMI.

\section{El Prometeo de Marx y la ética del sujeto}

Según mi opinión, en esta situación se vuelve central lo que Marx presenta como su Prometeo, muy diferente de todos los otros. Ya destaqué, que el Prometeo del joven Marx realiza un discernimiento de los dioses, que no aparece en ninguno de los otros. Pronuncia una sentencia sobre todos los dioses en el cielo y en la tierra, que no asumen al ser humano -este ser consciente de sí mismo-, como divinidad suprema, que toleran que el ser humano sea "un ser humillado, sojuzgado, abandonado y despreciable". Una sentencia sobre los dioses en el cielo y en la tierra, que no comprenden que este ser así descrito, representa una violación de la divinidad suprema. Y cuando Marx deja de hablar de los dioses, habla en relación a este ser humillado, sojuzgado, abandonado y despreciable como la esencia suprema del hombre para el hombre. Es una esencia hecha sujeto.

Este ser humillado, sojuzgado, abandonado y despreciable como trabajador resulta ser su Prometeo: "Finalmente, la ley que mantiene siempre la superpoblación relativa o ejército de reserva en equilibrio con el volumen y la intensidad de la acumulación, mantiene al obrero encadenado al capital con grilletes más firmes que las cuñas de Vulcano con que Prometeo fue clavado a la roca"17.

Clavado en la roca vive su martirio. Es el Prometeo del cual ha dicho: "En el calendario filosófico, Prometeo ocupa el primer rango entre los santos y los mártires”. El martirio de este Prometeo es el martirio del ser humillado, sojuzgado, abandonado y despreciable: "En la agricultura, el igual que en la manufactura, la transformación capitalista del proceso de producción es a la vez el martirio del productor, en que el instrumento de trabajo se enfrenta con el obrero como instrumento de sojuzgamiento, de explotación y miseria, y la combinación social de los procesos de trabajo como opresión organizada de su vitalidad, de su libertad y de su independencia individual"18. Y agrega que "la transformación del proceso de producción es a la vez el martirio del productor"19. "Al convertirse en un autómata, el instrumento de trabajo se enfrenta como capital, durante el proceso de trabajo, con el propio obrero; se alza frente a él como trabajo muerto que domina y chupa la fuerza de trabajo viva" ${ }^{20}$. Es el Prometeo al cual se le extrae la fuerza viva de trabajo.

Este Prometeo de Marx está encadenado en la roca. Evidentemente, tiene un águila que le chupa la sangre y devora su hígado y ésta es mandada por un Zeus. En el libro de Luri Medrano aparecen muchas águilas. La predominante es que sea entendida como inquietud humana, como cura o como Sorge, en el lenguaje de Heidegger. Cicerón interpreta el águila como el cuerpo que tortura el $\mathrm{alma}^{21}$. En otros posteriores puede ser el amor. Cabe señalar que en estas historias de Prometeo no aparece la inquietud principal, a la cual apunta Marx: la inquietud y el miedo de ser tratado como un ser humillado, sojuzgado, abandonado y despreciable. 

tortura al cuerpo dominado por el sistema, que en la modernidad opera a través de la ley, cuya base es la ley del valor. El águila es cuerpo y tortura al alma. Es evidente que Cicerón habla en nombre del señor y amo, que se siente torturado por las expresiones de las necesidades corporales de sus dominados. Marx, en cambio, habla en nombre de estos dominados, los cuales son humillados, sojuzgados, abandonados y despreciados por el señorío de sus señores. Cicerón. Aparecen entonces los instintos no domesticados, que torturan al yo, son su águila, que hace falta domesticar. Sin embargo, eso no hace desaparecer el punto de vista del Prometeo de Marx. Pues, en cuanto el yo o la autoridad ejercen esta domesticación por medio de la ley, transforman los cuerpos de los sometidos en seres humillados, sojuzgados, abandonados y despreciados. Prometeo, pero Zeus es quien le ordena hacerlo. El Prometeo de Marx sabe que es el sistema de poder, el que, en cuanto sistema, manda al águila. En la siguiente cita, que aparece en un lugar clave del primer tomo de El Capital, este mismo Zeus es cuestionado; se la llama ahora "reina de los mares": "Y frente a la vieja reina de los mares se alza, amenazadora y cada día más temible, la joven república gigantesca: 'Un duro destino atormenta a los romanos, la maldición por el crimen del asesinato del hermano' (Horacio)"22.

58 Hay dos referencias al tiempo de los romanos. La primera es a la reina de los mares. En la antigüedad Roma ostentaba dicho nombre. En el tiempo de Marx, el imperio británico es quien ha asumido este título. La diferencia es obvia. Roma como reina de los mares sólo regía sobre el mar mediterráneo. Inglaterra era la reina -o pretendía serlo-, de todos los mares de la tierra. Es una reina universal comparándola con Roma, que era reina local, inclusive provincial.

tra referencia a Roma está en la cita que Marx hace de Horacio. Ésta revela algo, que vale para todas las referencias a la antigüedad griega y romana, desde el Renacimiento. Implica una resignificación fundamental. Horacio no dice lo que Marx le imputa, aunque lo dice. La cita de Horacio es parte de un largo poema. En ese contexto, el duro destino de los romanos por el asesinato del hermano se refiere directamente a las guerras civiles que perturbaron a Roma desde la rebelión de Catilina hasta la constitución del imperio por el emperador Augusto. Es un período de guerras civiles intestinas. Según Horacio, los romanos son hermanos entre sí, los pueblos sojuzgados no aparecen como tales, y su asesinato no es visto como asesinato del hermano.

Marx extrae la cita fuera de su contexto y le otorga un significado diferente. El asesinato del hermano es ahora el asesinato de los subyugados por el imperio. Las guerras civiles no son más que una consecuencia. Este asesinato subvierte al propio imperio, que para el Prometeo de Marx es ahora el imperio británico, como actualmente para nosotros es el imperio de Estados Unidos, que se ha convertido en la nueva reina de los mares. Ahora bien, el asesinato del hermano, sobre el cual descansa su poder, no mata solamente a estos hermanos. Se dirige en contra del imperio mismo, lo condena y lo destruye desde adentro. El asesinato del hermano desemboca en el suicidio del asesino. Tal es el "duro destino" que "atormenta a los romanos". 
61 Zeus, que desde el Olimpo del imperio envió al águila a torturar a Prometeo, prepara su propia muerte. En el mito griego de Prometeo, Zeus sabe que su régimen está amenazado por su derrocamiento. Prometeo sabe el secreto, pero no lo revela. El Prometeo de Marx lo devela: Zeus será derribado por las consecuencias de la acción torturadora y asesina del águila que envió para torturar a Prometeo. Los falsos dioses, sobre los cuales Prometeo da su sentencia, encuentran su derrota porque el asesinato que cometen conlleva su propio suicidio. El Prometeo de Marx, que aquí se presenta, es una reconstrucción a partir de elementos que aparecen en sus textos sólo en forma de esbozo. Sin embargo, estoy convencido que expresa adecuadamente lo que Marx percibe como su Prometeo.

\section{El sistema de mercado sacralizado}

62 El sistema se manifiesta a sí mismo como un hecho social muy escueto, pero aún así, se presenta con un velo sagrado. Marx critica este recurso de Hegel, en su Introducción a la crítica de la filosofía del derecho de Hegel de 1844. Pero, ciertamente su propósito no se agota en criticar el sistema filosófico de este pensador. El sistema social actual se presenta también como un sobremundo sagrado, que se impone a las voluntades humanas y tiene el derecho de hacerlo. Esta concepción está presente en Luhmann, para el cual el sujeto está fuera y por tanto expulsado del sistema. Sin embargo, prefiero mostrarlo en Hayek, a pesar de que la cita resulta un poco larga. Su pensamiento es interesante por el tipo de sacralización que produce.

"No existe en inglés o alemán palabra de uso corriente que exprese adecuadamente lo que constituye la esencia del orden extenso, ni por qué su funcionamiento contrasta con las exigencias racionalistas. El termino "trascendente", el único que en principio puede parecer adecuado, ha sido objeto de tantos abusos que no parece ya recomendable su empleo. En su sentido literal, sin embargo, alude dicho vocablo a lo que está más allá de los límites de nuestra razón, propósitos, intenciones y sensaciones, por lo que sería desde luego aplicable a algo que es capaz de generar e incorporar cuotas de información que ninguna mente personal ni organización singular no sólo no serían capaces de aprehender, sino tan siquiera de imaginar. En su aspecto religioso, dicha interpretación queda reflejada en ese pasaje del padre nuestro que reza "hágase tu voluntad (que no la mía) así en la tierra como en el cielo", y también en la cita evangélica: "No sois vosotros quienes me habéis elegido, sino Yo quien os eligió para que produzcáis fruto y para que este prevalezca" (San Juan, 15:26). Ahora bien, un orden trascendente estrictamente limitado a lo que es natural (es decir, que no es fruto de intervención sobrenatural alguna), cual acontece con los órdenes de tipo evolutivo, nada tiene que ver con ese animismo que caracteriza a los planteamientos religiosos, es decir, con esa idea de que es un único ente, dotado de inteligencia y voluntad (es decir, un Dios omnisciente), quien, en definitiva, determina el orden y el control"23.

El sistema, del cual Hayek habla, es el del mercado. Afirma que éste es trascendente en relación a toda actuación humana, y como tal exige sometimiento irrestricto. Dicho sometimiento Hayek lo explica mediante ciertas citas bíblicas, predilectas de la ortodoxia cristiana. Su uso es llamativo. Sacralizan el sistema, sin duda, pero Hayek insiste que esta sacralización no la entiende en sentido religioso. Según él, se trata únicamente de una referencia de erudición y metafórica, sin embargo, sirve para sacralizar el mecanismo del mercado. De esta manera, se distancia de lo que llama el "animismo" religioso, el cual daría al sistema una existencia sustancial con voluntad propia. El no quiere decir eso; 
quiere presentar el sistema como un sujeto sustitutivo, cuya autoridad incuestionable se deriva del mismo mecanismo del mercado.

Sin embargo, lo transforma en algo legítimo en sí mismo. Lo hace en términos de la filosofía del "como si" de Vaihinger. Lo que Hayek tanto aprecia es una divinidad "como si" lo fuera, aunque no lo es. Es un tipo de argumentación post-renacentista, que resulta necesaria para afirmar un universalismo del sistema independientemente de cualquier fe religiosa que pudiera existir. No quiere un Dios omnisciente, pero sí un mecanismo de regulación, que es "como si" fuera omnisciente. También lo llama un milagro, pero otra vez en el sentido de que es "como si" fuera un milagro.

El resultado al cual llega Hayek, es el esperable. Este es la exigencia de sometimiento al sistema y de colaboración con éste, sin considerar ninguna de las consecuencias que esto pudiera implicar. Son las reglas (las leyes del mercado) que organizan y que asumen la responsabilidad. Todo otro comportamiento frente a ellas sería hibris y rebeldía. Es el resultado al cual también Agustín de Hipona había llegado y que ya comenté: es el de la divinización por participación y no por rebeldía o crítica. Llega al mismo resultado, aunque sin el "animismo" de Agustín. Hayek lo dice con estas palabras: "por un lado, (encontramos) el individualismo, que es humilde en su esencia, trata de entender las reglas, según las cuales los esfuerzos de cada uno han colaborado para hacer surgir nuestra civilización y espera sobre la base de esta compresión poder crear las condiciones favorables para un desarrollo posterior, y por el otro lado, la hibris del colectivismo, que quiere dirigir concientemente todos los esfuerzos de la sociedad" ${ }^{24}$.

Marx responde a este tipo de sistema capitalista, en términos teóricos igualmente escuetos. Analiza dicho sistema a partir del trabajo humano y construye su representación como un circuito. El productor-trabajador, al desarrollar la división social del trabajo, promueve el mercado, pero de una manera indirecta y no-intencional: "En su perplejidad, nuestros poseedores de mercancías piensan como Fausto: en principio, era la acción. Por eso se lanzan a obrar antes de pensar. Las leyes de la naturaleza propia de las mercancías se cumplen a través del instinto natural de sus poseedores" 25 .

Este mercado se desarrolla como sistema de mercancía, dinero y capital, y adquiere el poder sobre los propios productores, que se convierten en seres dependientes de éste. $\mathrm{Al}$ transformarse el sistema en capitalista, convierte al productor en trabajador dependiente frente a los medios de producción, que lo dominan como propiedad. Todo eso ocurre como consecuencia de un desarrollo de la racionalidad formal y de una legalidad basada en la contractualidad. El propietario ahora adquiere un poder arbitrario, sin romper los marcos de la legalidad formal. Se siente libre. Sin embargo, el productor es transformado en "un ser humillado, sojuzgado, abandonado y despreciable". Pero, no solamente el productor es transformado en objeto explotado, la propia naturaleza externa, sobre la cual gira el trabajo humano, es igualmente transformada. Se produce un sistema del cual Marx puede decir: este efecto también ocurre, por tanto, como efecto indirecto, que a veces incluso es no-intencional. "Por tanto, la producción capitalista sólo sabe desarrollar la técnica y la combinación del proceso social de producción socavando al mismo tiempo las dos fuentes originales de toda riqueza: la tierra y el trabajador" ${ }^{26}$. Se trata de un asesinato que se convierte en un suicidio.

69 Este circuito da entonces una doble vuelta. Produce el sistema del mercado como su efecto indirecto, porque es la forma dentro de la cual el desarrollo de las fuerzas productivas se hace posible y coordinable en la división social del trabajo. Sin embargo, el sistema que se genera en este proceso se transforma en dominador, y transforma al 
productor-trabajador, del cual todo partió, en un ser explotado y despreciado. Lo hace igualmente de una manera indirecta y, por tanto, inevitable en el grado en el cual se puede totalizar como sistema del mercado total, algo que actualmente y de nuevo promueve la estrategia de globalización.

Es fácil expresar eso con las metáforas míticas del mito de Prometeo. Al apropiarse del fuego desata el proceso de desarrollo de las fuerzas productivas; e impulsa hacia la constitución de un sistema de coordinación de la división social del trabajo, que se transforma en un poder. Éste transforma a Prometeo en ese ser torturado y despojado. Al no poder dar cuenta de estas transformaciones, constituye el sistema como poder divino, en su Zeus. La entidad trascendente, sobre la cual Hayek está fantaseando en la cita de más arriba, no es más que este Zeus, el falso dios del sistema. Al someterse el productor a Zeus, éste le envía el águila para que lo torture como castigo por el "robo" del fuego.

71 Ahora, la clase dominante se interpreta a sí misma como el Prometeo titánico, para el cual el águila es la "inquietud", la presión, la infelicidad. Es su efecto indirecto derivado de su gigantismo y el castigo que tiene que aceptar es su stress. Se siente libre al poder explotar y despreciar a los otros, aunque como consecuencia tiene que explotarse y despreciarse a sí misma también. En cambio, la clase dominada, si se interpreta como Prometeo clavado a la roca, ve en el águila esta fuerza que la explota y desprecia. Este es, ciertamente, el sistema en que vivimos. Sin embargo, al divinizarlo, el sistema se fetichiza y la concatenación de efectos indirectos o no-intencionales de la acción se hace invisible. El ser humano parece condenado a sufrirlo y a someterse. Deja de ser sujeto de su propia vida. Marx habla, en relación con este proceso de fetichización, de la "religión de la cotidianidad" (Alltagsreligion).

Hacerse libre frente a este sistema, implica una crítica de la religión. Es la crítica de los dioses de esta tierra, en cuanto no reconocen al sujeto humano como divinidad suprema. Esta libertad implica a la vez la ética del sujeto. No hay libertad si no se llega a controlar y canalizar todo el circuito para recuperar al productor-trabajador como el centro alrededor del cual tiene que girar todo lo demás.

\section{La ley como cárcel del cuerpo}

El análisis muestra que el Prometeo de Marx es único, y tiene el carácter de una respuesta a todos los otros Prometeos que han surgido desde el Renacimiento. La clave para entender este Prometeo es su específica referencia al cuerpo. Se basa en la inversión de la conceptuación platónica. En esta tradición se afirma que el cuerpo es la cárcel del alma, la cual se siente desterrada y el cuerpo es el lugar del destierro. El mismo Cicerón interpreta, como vimos, el águila de Prometeo como el cuerpo que tortura al alma. En Marx aparece la inversión: la ley, y ésta es para Marx es la ley del valor, es la cárcel del cuerpo. Prometeo está clavado en la roca por la ley y el águila, por tanto, es el torturador mandado por la ley. Ésta se convierte en una jaula y no puede haber liberación sino de ella.

Se muestra que esta clave del Prometeo de Marx no es griega. Se encuentra, precisamente, en los orígenes del sujeto cristiano, aunque todavía con su envoltura religiosa. No se puede entender el sujeto que presenta San Pablo y la propia promesa de la resurrección del cuerpo, sino a partir de esta inversión. La liberación significa liberar al cuerpo de la ley, aunque posteriormente la ortodoxia cristiana lo va a invertir 
nuevamente en contra del cuerpo. Eso inclusive con muchas ambivalencias en los propios textos de San Pablo. Dicha inversión aparece por ejemplo en este texto suyo: "Y no sólo el universo, sino nosotros mismos. Aunque se nos dio el Espíritu como anticipo de lo que tendremos, gemimos interiormente, esperando el día en que Dios adopte y libere nuestro cuerpo"27.

Se trata de liberar el cuerpo de la ley, a diferencia del pensamiento griego que quiere liberarse del cuerpo, lo que la gnosis lleva a una posición extrema. Desde el Renacimiento, este es un elemento clave del desarrollo de la modernidad. Lo es, aunque luego la liberación corporal fue sustituida por la liberación ilimitada de la persecución de intereses materiales, que crea en el mercado una nueva cárcel para el cuerpo.

Cuando Marx recupera al sujeto, busca rescatarlo de esta nueva cárcel del cuerpo que es el sistema del mercado. Pero al hacerlo, universaliza el sujeto humano corporal y necesitado más allá de toda envoltura religiosa. Es tan universal como pretende serlo el mercado. Marx no es el único que concibe el sistema de mercado como una cárcel del cuerpo. Max Weber dice lo mismo cuando habla del capitalismo como de una "jaula de acero". Weber no es tan superficial en su apreciación como lo es Hayek y los neoliberales al celebrar el mercado y el capitalismo como un reino de la libertad ${ }^{28}$. Sin embargo Weber no llega a la conclusión de Marx, esto es, que el sujeto humano es la esencia suprema del ser humano. Lo evita por su actitud fatalista. No celebra el capitalismo, sino lo considera como un fatalismo sin límites. Por tanto, concibe una ética fatalista, de sometimiento, frente a la ética afirmativa del sujeto, que desarrolla Marx. Weber ya se acerca a lo que hoy es la prédica desarrollada del sistema de mercado: no hay alternativa: TINA (There is no alternative), como solía decir Margaret Thatcher.

Marx, en su tiempo, se enfrenta a tales concepciones fatalistas citando las palabras que el Prometeo de Esquilo dirige a Hermes, el mensajero-sirviente de Zeus, quien lo quiere convencer de que se someta a la voluntad del dios argumentando desde la fatalidad de su situación, por estar clavado en la roca: "Con tu servicio servil no quisiera jamás intercambiar ésta mi suerte miserable,escucha bien, jjamás, jamás! Si, es más bello estar sometido a esta roca que servir lealmente al padre Zeus como sirviente fiel" 29 .

Este Prometeo, tanto el de Esquilo como el de Marx, no se rinde, aunque fatalmente no tenga alternativa. Descubre la dignidad más allá del cálculo del éxito. Precisamente, por eso puede encontrar la salida en el caso de que la haya. Weber, en cambio, adopta el papel del mensajero-sirviente de Zeus y a esa sumisión la llama "ética de la responsabilidad". Sin embargo, es la irresponsabilidad pura. Ni la muerte es aceptable por la razón de que sea una fatalidad sin salida. Los mensajeros-sirvientes de Zeus piden la sumisión de un ser humano, al cual declaran un "ser para la muerte". Pero el ser humano es un ser para la vida, atravesado por la muerte, que ocurre fatalmente. Pero, no es un ser para la muerte, ni para el eterno retorno de lo mismo, que es otra expresión del sometimiento a la fatalidad de la muerte.

79 Esta situación la vemos también en el caso de la muerte de Jesús. Antes de su muerte y sabiendo que no tenía ya escape frente a aquellos que estaban decididos a matarlo, según el texto de los evangelios, se retiró al monte de olivos. Allá experimentó el miedo y por ello sudó sangre. Frente a su Dios-padre decía: "que se cumpla tu voluntad". La ortodoxia cristiana lo interpreta en el sentido de que la voluntad de Dios era que Jesús fuera crucificado. El texto es diferente y eso se ve con más claridad en los diálogos de Jesús con Pilatos en el evangelio de Juan. Independientemente de que lo maten o no, él sigue su camino. Independientemente de que lo maten o no, insiste en su razón frente a la 
injusticia de su muerte. Con independencia de que lo maten o no, sigue fiel a sí mismo. Eso, para él, es la voluntad de Dios y en eso consiste su obediencia. Es la obediencia del ser humano como sujeto, cuyo Dios tiene como su suprema divinidad el ser humano que se asume a sí mismo. En este caso, Jesús está en la misma posición en la que se encuentra el Prometeo de Esquilo, y la asume igualmente. Rechaza la salvación por la servidumbre y el sometimiento: Dios se ha hecho hombre. La ortodoxia cristiana se puso del lado de Zeus y habla con la voz de su mensajero, Hermes. A su paso le siguen igualmente las ortodoxias liberales y marxistas cuando asumen su sistema respectivo como suprema divinidad.

Sin embargo, esta afirmación del sujeto desemboca en una ética, como se ve en las palabras ya citadas de Marx: "el hombre es la esencia suprema para el hombre y, por consiguiente, en el imperativo categórico de echar por tierra todas las relaciones en que el hombre sea un ser humillado, sojuzgado, abandonado y despreciable". Esta afirmación presupone otro juicio: yo soy si tú eres. Es la ética de la autorrealización del ser humano por la afirmación de su subjetividad. Es la autorrealización subjetiva, algo que no podemos hallar en Esquilo. La habíamos encontrado en los orígenes del cristianismo. Sin embargo, aparece ahora como una formulación de alcance universal más allá de cualquier fórmula religiosa.

El ser humano es la esencia suprema del ser humano. La raíz del ser humano es el mismo ser humano. Esta esencia no es ni una ley natural, ni un a priori de valores. Es la afirmación del ser humano como sujeto, pero adquiere su especificidad por la vivencia de las violaciones a la dignidad humana. Asume el carácter de exigencia ética en cuanto que el sujeto humano no se somete a estas violaciones, sino se enfrenta a ellas. Ahora bien, que son violaciones es algo que descubre, no se sabe a priori. Desde el punto de vista del sistema de dominación, todas las violaciones son presentadas como necesidad fatal de la existencia del sistema y por tanto del orden. Es el sujeto quien las enfrenta en cuanto no acepta esta fatalidad aparente o real como última instancia. Frente a las violaciones específicas desarrolla exigencias, y éstas son expresadas como derechos humanos, que inclusive llegan a legalizarse, y las violaciones de la dignidad humana son ilegales, pero la ilegalidad no es su esencia. Antes de las legalizaciones de los derechos humanos, se experimentan como violaciones. No es la legalidad lo que las transforma en tales -no lo son a consecuencia de una ley violada-, sino que se descubren como violaciones con anterioridad a cualquier ley que las prohíba. La ley ilegaliza algo que es ilegítimo ya antes de la ley. A posteriori se descubren las violaciones de los derechos humanos, pero lo que se descubre, es una aprioridad de una esencia humana violada. Se descubren en el curso de la vida cotidiana. Lo que es a priori, se descubre a posteriori. Una vez descubiertos, se ve que son a priori. Por eso, no se trata ni de una ley natural, ni de un listado a priori de valores específicos. Los derechos humanos que resultan de este proceso, tienen una historia, a lo largo de la cual van apareciendo.

Cuando Marx formula esta ética del sujeto corporal, necesitado y vulnerable, habla de un nuevo imperativo categórico. Se trata de una respuesta a la ética de Kant, la de la crítica de la razón práctica. Efectivamente, la ética de Kant es una ética de la ley y de las normas. Su imperativo categórico define el acto ético como un acto de cumplimiento de normas universales. Kant explícitamente pone el cumplimiento de las normas abstractas como una obligación por encima de la vida humana misma: fiat iustitia, pereat mundus (que haya justicia -en sentido del cumplimiento de las normas formales-, aunque perezca el mundo). He aquí su rigorismo. La autonomía de su ética es una autonomía de leyes y normas, que excluye la autonomía del ser humano. Transforma al ser humano en un 
servidor de la ley del imperativo categórico. En cambio, la ética que Marx recupera es una ética de la autonomía del ser humano como sujeto corporal y necesitado. Afirma su soberanía frente a las leyes. No produce su abolición, pero las transforma en soportes de la vida humana, del sujeto humano. No tienen ningún valor en sí, y si son necesarias lo son en el mismo sentido en que el lisiado requiere de las muletas. Las leyes tienen que adaptarse para permitir que sea posible la vida del sujeto, y no existen sino en función de esta vida.

La ética de Kant es una ética estática; la que formula Marx es una ética de la transformación y del cambio: el imperativo categórico de echar por tierra todas las relaciones en que el hombre sea un ser humillado, sojuzgado, abandonado y despreciable, es el llamado a cambiar toda ley, toda institución en cuanto humille, sojuzgue, abandone y desprecie al ser humano. El ser humano como sujeto es el criterio de juicio sobre todas las leyes y todas las instituciones.

84 En la visión de Kant, este punto de vista es propio de una ética heterónoma, externa. Es así porque Kant, dogmáticamente, pone a la ley como única instancia de la autonomía ética. Esta no tiene sujeto humano, sino en sí misma es sujeto y determina externamente al ser humano -en nombre de la no-contradictoriedad de la razón práctica-, lo que es bueno y lo que es malo, si tiene que vivir o morir. Si su no-contradictoriedad lo exige, pasa por encima de la vida humana. Su misma esencia es heterónoma al ser humano viviente. La ética del sujeto cuestiona esta exterioridad de la ley formal, y por eso la invierte. La autonomía supone la relación entre seres humanos que relativizan toda ley cuando su cumplimiento humilla, sojuzga, abandona o desprecia al ser humano.

La ética del sujeto sitúa, efectivamente, al ser humano como sujeto en el centro de toda la historia humana, de todas las instituciones y leyes posibles. Lo pone como punto de partida, por eso convierte al ser humano humillado, sojuzgado, abandonado y despreciado en el criterio de discernimiento de las instituciones y leyes. Como tal, hace de él la verdad de la historia, una verdad constantemente traicionada en ella, pero que, como verdad ausente, está siempre presente. A ella se refiere Walter Benjamin cuando escribe: "Es notorio que ha existido, según se dice, un autómata construido de tal manera que resultaba capaz de replicar a cada jugada de un ajedrecista con otra jugada contraria que le aseguraba ganar la partida. Un muñeco trajeado a la turca, en la boca una pipa de narguile, se sentaba al tablero apoyado sobre una mesa espaciosa. Un sistema de espejos despertaba la ilusión de que esa mesa era transparente por todos los lados. En realidad se sentaba dentro un enano jorobado que era un maestro en el juego del ajedrez y que guiaba la mano del muñeco mediante hilos. Podemos imaginarnos un equivalente de este aparato en la filosofía. Siempre tendrá que ganar el muñeco que llamamos "materialismo histórico". Podrá habérselas sin más ni más con cualquiera, si toma a su servicio a la teología que, como es sabido, hoy es pequeña y fea y no debe dejarse ver en modo alguno" 30 .

Lo que Benjamin llama materialismo histórico es esta ética del sujeto, la cual contiene a la vez necesariamente la referencia al discernimiento de los dioses. Es el criterio que establece el Prometeo de Marx: en contra de todos los dioses del cielo y de la tierra, que no reconocen la autoconciencia humana (el ser humano conciente de sí mismo) como la divinidad suprema. Al lado de ella no habrá otro Dios. La sentencia se pronuncia en nombre del sujeto humano corporal y necesitado. De la ética del sujeto se deriva este discernimiento de los dioses. La divinidad de Dios gira alrededor de este sujeto, que en cuanto exigencia es siempre un sujeto presente por ausencia, por cuya presencia positiva 
siempre se lucha. En última instancia, este sujeto humano presente por ausencia es Dios. Este discernimiento de los dioses contiene una evidente crítica de la idolatría y de los dioses idolátricos. Estos son los dioses derivados de la vigencia de la ley y de las instituciones por encima de la vida humana.

Kant deriva de su ética postulados de la razón práctica, que afirman la libertad, la inmortalidad y la existencia de Dios. La ética del sujeto no afirma estos postulados. Evidentemente, presupone un postulado de libertad: es el postulado de que el ser humano es libre para afirmar su vida frente a las leyes, las instituciones y los ídolos. Siempre es libre y por eso siempre hay alternativas. Pero, no necesita afirmar la existencia de la inmortalidad ni la existencia de Dios. También los dioses puramente imaginados deben ser sometidos al discernimiento y la ética del sujeto produce este discernimiento. No implica un juicio de existencia, es decir, no implica ninguna afirmación de tipo metafísico tradicional. Por eso es también un criterio de discernimiento sobre el ateísmo. Pues, un ateísmo que no condena los dioses idolátricos, es él mismo idolátrico y se transforma en otro tipo de metafísica. Por eso, hay una diferencia decisiva entre el ateísmo de Marx y el del socialismo soviético. La ortodoxia soviética es metafísica, el ateísmo de Marx no es metafísico, sino humanista. Por eso, la opinión de Marx es que con la afirmación de la ética del sujeto la religión va a morir. Pero eso es simplemente una opinión y no un resultado necesario de su análisis. Una opinión, que, además, es probablemente errónea. Sin embargo, para la ética del sujeto y el consiguiente discernimiento de los dioses es irrelevante.

El juicio sobre la existencia de Dios, que Kant deriva de su razón práctica, es una variación de la antigua prueba ontológica de Anselmo de Canterbury. Por supuesto, se puede hacer algo análogo desde la ética del sujeto; pero el Dios que resulta es un Dios de la liberación, que libera al cuerpo de la ley. Sin embargo, esta prueba no es relevante para el análisis que hace esta ética, y siempre conserva el problema, reconocido por el mismo Anselmo, de ser una prueba para creyentes. El discernimiento de los dioses se mueve en otro nivel. Es análisis de la realidad concreta y perceptible. Sin embargo, sigue empujando la pregunta por el ser real de estos dioses. Es la pregunta: ¿qué pasa con esta ciencia moderna en cuanto se la mira en conjunto bajo la perspectiva: etsi deus daretur(como si Dios existiera)? La pregunta no desaparece y cualquier análisis propiamente teológico tiene que enfrentarla. Pero, se refiere ahora al conjunto de la ciencia moderna. Ahora bien, para poder desarrollar eso, se necesita previamente haber hecho el análisis de la teología (y toda la ciencia moderna) bajo el: etsi deus non daretur(como si Dios no existiera). Una vez que ha llegado hasta la teología, el análisis desemboca en un replanteamiento completo. El discernimiento de los dioses, entonces, conduce a la afirmación: si Dios habla al ser humano, este ser humano es responsable de lo que Dios dice.

Es significativo el hecho de que la tradición marxista no ha seguido desarrollando esta ética del sujeto. En el posterior desarrollo del pensamiento de Marx -y sobre todo en sus análisis del fetichismo-, se mantiene su presencia, aunque no realiza una elaboración sistemática. Probablemente, la razón de ello se encuentre en el hecho de que progresivamente el movimiento socialista entendió el socialismo como meta definitiva de la historia, y por eso concibió la transición al socialismo como una acción de transformación institucional, para la cual esta ética parecía irrelevante, por tanto, la dejó de lado. Pero, al proceder así construyó un sistema con características centrales parecidas a los sistemas anteriores; el ateísmo metafísico que cultivó en su seno resultó ser un 
ateísmo idolátrico (también los ateísmos pueden ser idolátricos). El Prometeo de Marx no lo aceptaría y lo condenaría al igual que a los sistemas anteriores.

Sin embargo, este tipo de construcción de metas definitivas de la historia humana fracasó. Ya la filosofía de Nietzsche había pronosticado el colapso del propio mito del progreso, en el cual se basan las construcciones de dichas metas. La misma concepción soviética del tránsito al socialismo no era más que una derivación de este imaginario abierto por el mito del progreso. La historia no tiene metas definitivas intrahistóricas, pero sí tiene caminos. Hay caminos de liberación, pero los logros no se miden en función de una meta futura por alcanzar, sino por el logro en cada momento presente de la historia.

El cambio que proponemos en relación a las metas definitivas, proyectadas sobre un futuro infinitamente largo, tiene que partir de un cambio en la relación de los hombres con las macroinstituciones del Estado y del mercado. Es sabido que desde la perspectiva socialista se proyectó su desaparición (o minimización) y se concibió como meta una convivencia más allá de estas instituciones. La utopía soviética del comunismo implicaba, claramente, la abolición del Estado y del mercado. La experiencia soviética nos obliga a cambiar la concepción de la sociedad futura: estas macroinstituciones resultan ser un límite infranqueable para toda acción humana. No son producto intencional de la acción humana, sino indirecto y muchas veces no-intencional de esta acción, y se imponen aunque los actores hagan todo para evitarlo. Aparecen ahora como consecuencia de la propia condición humana, es decir de la contingencia del mundo y de la presencia de la muerte en ella. Todo es contingente, pero la contingencia no lo es. Por tanto, en cualquier escenario futuro, ambas instituciones son el marco de cualquier acción social.

Sin embargo, por eso no son estáticas o invariables. Representan el marco de variabilidad de la acción humana. Pueden ser modificadas y controladas, mediante la acción, pero no pueden ser abolidas o superadas. Desde esta perspectiva, cambia toda la relación con la utopía. Partimos ahora de lo presente para cambiar situaciones presentes. Lo hacemos con una dimensión y anticipación en el tiempo que siempre es limitada y cambiante, guiada por la vida humana y sus condiciones de posibilidad.

Con eso aparece otra dimensión de la cuestión, que constituye, actualmente, una de las bases de la estrategia de globalización. Dentro de ella, se considera este límite infranqueable, representado por la existencia de estas macroinstituciones, como razón para la imposición de estas instituciones sin respetar ningún marco de variabilidad. Se concibe la salvación por la totalización de estas instituciones, ya sea la totalización a partir del Estado en el pasado, ya sea , actualmente, por la totalización a partir del mercado. La segunda desemboca, paradójicamente, en una totalización del Estado como su condición de posibilidad. Con eso desaparece la política -se impone la postura de que "no hay alternativas"-, y se establece el dominio absoluto de las burocracias privadas de las grandes corporaciones empresariales.

En esta totalización se mantiene la infinitud como proceso infinito en el tiempo, pero es ahora una infinitud vacía y sin sentido. El progreso infinito en el tiempo sigue dominando, pero deja de ser progreso por el hecho de que no va a ninguna parte. Es el tiempo del nihilismo. Es el titanismo después del hundimiento del Titanic. El Prometeo correspondiente, que empujó el viaje del Titanic, no se ha escrito aún. ¿O será el Prometeo de Marx? 


\section{El retorno actual a la ética del sujeto}

95 Cuando todo esto se hace consciente, reaparece la ética del sujeto, cuyo criterio va más allá de cualquier meta futura y definitiva. Como dice un cantante brasilero: "el amor es eterno todo el tiempo que dura". Este más allá está ahora en el presente, en cada momento que vuelve sobre sí mismo. Reaparece desde un espacio teórico poco esperable: el de la teología de liberación y la filosofía de liberación latinoamericanas. En estas corrientes, esta ética está más sistemáticamente elaborada que en Marx, aunque es significativa la semejanza con el modo que este pensador presenta su ética. Pero, eso no se explica por dependencia al pensamiento de Marx, sino por el hecho de que en ambos casos está presente la raíz cristiana de la misma. Al igual que en Marx, también en estas corrientes latinoamericanas la ética del sujeto es elaborada en términos de una ética autónoma. En su teología de liberación, Gustavo Gutiérrez expresa, explícitamente, este hecho. Habla de la teología como un acto segundo a partir de una praxis interpretada en términos de una ética del sujeto. Enrique Dussel hace de esta necesidad de la autonomía de una ética de liberación uno de los centros de su argumentación"31.

Dostoyevski dijo: "si Dios no existe, todo es posible". Eso es evidentemente falso. El mayor crimen de nuestra historia -la "solución final" del nazismo en Alemania-, fue cometido en nombre de Dios, del "Omnipotente", de la "Providencia". Abundan los crímenes en nombre de Dios. Pero, la inversión de esta afirmación tampoco es cierta: "si existe Dios, todo es posible". Sin embargo, hay una sentencia, que puede esclarecer el problema: "si se acepta el suicidio, todo es posible". Proviene de Camus y está implícita a toda su obra. Ésta también es muy cercana a las reflexiones de Wittgenstein sobre el suicidio ${ }^{32}$, y corresponde igualmente a las reflexiones citadas de Marx. Pero, corresponde especialmente a la teología de Karl Barth. La ética del sujeto surge al renunciar al suicidio, en consecuencia, todas nuestras acciones hay que canalizarlas en función de nuestra vida, la mía y la de los otros. Eso permite el discernimiento de los dioses y de los ateísmos. Por eso, esta sentencia corresponde al carácter autónomo de la ética del sujeto. En última instancia, los dioses falsos son aquellos que permiten el suicidio o empujan hacia él. Hoy son los dioses en nombre de los cuales se empuja la estrategia de globalización, cuya esencia es asesina y suicida. Son los dioses del fundamentalismo actual, sea de los fundamentalismos cristianos u otros. Explícitamente, en el plano religioso reproducen el gran suicidio colectivo que está en curso con la aplicación de la estrategia de globalización en el mundo entero ${ }^{33}$.

Una vez desarrollada la ética del sujeto como ética autónoma, es posible desarrollar desde ella una articulación entre las religiones. Todas las religiones y todas las culturas tienen raíces en las cuales está presente la ética del sujeto. Hay que descubrirlas y elaborarlas. Pero, al ser esta ética una ética autónoma, su desarrollo en el interior de cada cultura no presupone la aceptación de ninguna religión para descubrirla. A la luz de esta ética, no hace falta convertir al otro a la religión propia ni, dado el caso, al ateísmo propio, o al revés. Sin embargo, si alguien se quiere convertir, que lo haga. Surge una nueva ecumene, en la cual hay una base común que a la vez tiene su presencia específica en cada una de sus corrientes. No se trata de convertir a otros, sino de despertar como sujeto desde la cultura en la cual uno se encuentra. Por esta razón, esta ecumene no genera fundamentalismos. La razón de ello está, precisamente, en el hecho de que la ética que los 
une es una ética autónoma más allá de cualquier envoltura religiosa. Sin embargo, según las culturas, puede asumir las más variadas formas religiosas, y de hecho las asume.

En este marco, los conflictos no desaparecen, sino que pueden reaparecer a partir de las idolatrías insertadas en cualquier tradición cultural. Pero el carácter idolátrico de esas expresiones se determina por criterios de la propia ética autónoma del sujeto. Por tanto, no se determina por criterios religiosos. Eso vale en general: el discernimiento de los dioses no se dirige por criterios religiosos, sino por los de una ética autónoma. Por estar sus elementos en todas las culturas, puede ser intercultural. Se trata de una ética humana que no es propiedad de nadie en especial.

Aparece una teología del: etsi deus non daretur (como si Dios no existiera). La ciencia moderna empezó con este etsi deus non daretur. Lo formuló primero un pensador escolástico -Alberto el grande-, cuyo discípulo fue Tomás de Aquino. Empezó por las ciencias naturales, para desembocar al fin en el propio análisis teológico. No se trata de una simple ciencia de la religión con su falsa objetividad, que solamente compara una religión con otra en función las imágenes religiosas que presenta cada una. Se trata efectivamente de una manera de hacer teología.

100 Anatotij Lunarcharski, quien fue ministro de cultura durante el gobierno de Lenin en la Unión Soviética, decía: "Si hay un Dios, Él es la vida, y la especie humana es su supremo representante" ${ }^{34}$. Eso es teología del "etsi deus non daretur", y ella efectúa un discernimiento de los dioses. En su raíz lleva a un discernimiento desde una ética del sujeto. Pero hay ejemplos contrarios. Hayek, el principal autor neoliberal, hace una reflexión del mismo tipo y llega a un resultado contrario: "Nunca supe el significado de la palabra Dios. Creo que es de suma importancia en la conservación de las leyes. Pero, insisto, como no sé el significado de la palabra Dios, no le puedo decir ni que creo ni que no creo en su existencia. Pero, también todos debemos admitir, simultáneamente, que ninguno de nosotros está en la posesión de toda la verdad. De 'toda' la verdad, dije. Y si usted me quiere definir a Dios como la verdad, en este caso estoy dispuesto a usar la palabra Dios. Es más: siempre que usted no pretenda poseer toda la verdad, yo estaría dispuesto a trabajar al lado suyo buscando a Dios a través de la verdad" ${ }^{35}$.

101 Hayek parte de la ética de la ley, que para él es ética de la ley del valor y del mercado. Un Dios de esta ley en el contexto del pensamiento de Hayek es un Dios de la verdad, entendiendo como tal el conocimiento de informaciones, y el hecho de que nadie dispone de todas las informaciones excepto Dios. Él hasta sabe el tipo de cambio de mañana y, por tanto, es bueno tenerlo como aliado. Por lo menos, es bueno para los negocios., y por tanto, aparecen los evangelios de la prosperidad.

Si ahora queremos discernir entre ambos dioses -entre la imaginación de Dios de parte de Lunarcharski y de Hayek-, no nos sirve ninguna tesis metafísica u ontológica referente a la existencia de Dios. Ambos piensan a partir de éticas autónomas, aunque sean contrarias: ética del sujeto y ética de la ley. Además, piensan en términos condicionales. A partir de sus éticas disciernen los dioses. Depende ahora de nuestro juicio sobre estas éticas la determinación de cuál de estos dioses es un ídolo y cuál no, pero este juicio no es religioso. Por tanto, este conflicto por la idolatría no es, tampoco, un conflicto religioso. Es el conflicto implicado en cualquier proceso de liberación, que supone, eso sí, la crítica de los dioses del sometimiento. No es un conflicto religioso, pero tiene una dimensión religiosa. 
Cuando empecé a trabajar en esta ética del sujeto, la consideraba una ética de trasfondo judío-cristiano. Con el tiempo me di cuenta hasta qué grado está presente en el pensamiento de Marx. Posteriormente la presenté a un grupo de africanos. Me contestaron: pero eso es africano. Entonces la discutí con grupos de indígenas que vienen a nuestros cursos en el DEI. La respuesta era: pero eso es nuestra tradición indígena. Después busqué en la literatura de otras religiones, y la descubrí tanto en pensadores islámicos como en pensamientos budistas e hinduistas. Ya no me quedan dudas de que se trata de algo presente en todas las culturas, a veces implícito, a veces traicionado, y a veces también defendido. Lo nuevo no es esta ética, sino su elaboración como ética autónoma y universal, que como tal puede expresar la verdad de todas estas corrientes sin ser propiedad de ninguna.

La teología de la liberación nace con este método y lo ha seguido desarrollando. Tiene antecesores importantes en la teología anterior, especialmente Karl Barth ${ }^{36}$ y Dietrich Bonhoeffer ${ }^{37}$. Por supuesto, introduce en sus análisis siempre también el análisis bajo el supuesto del "etsi deus daretur" (como si Dios existiera).

Ninguna ecumene parecida puede provenir desde el lado de los ídolos y de los dioses del sometimiento. Estos dioses transforman los conflictos seculares o de liberación en conflictos religiosos. Vuelven las guerras de religión. El actual gobierno de Bush defiende su dominio en nombre de un dios de este tipo. Es el dios de Estados Unidos, ciudadano de honor de aquél país, que llama a la guerra en nombre de la libertad, que es pretendidamente el regalo de este dios al mundo, siendo Estados Unidos su portaestandarte. De esta manera, aparecen los fundamentalismos, que de una manera parecida ejercen también influencias en el Islam. No surge ninguna posibilidad de constituir una ecumene.

Quiero terminar citando unas palabras de Ernst Bloch, que percibe la posibilidad de esta nueva ecumene, aunque todavía limitada a una ecumene entre marxismo y cristianismo: "Marx dice: 'Ser radical significa tomar las cosas desde su raíz. Pero la raíz de todas las cosas (es decir de las cosas sociales) es el hombre'. La primera carta de Juan $(3,2)$ en cambio, invita a interpretar la raíz-hombre no como la causa de algo, sino como el destino para algo: 'y todavía no apareció lo que seremos. Pero sabemos que cuando aparezca seremos igual a él; porque lo vamos a ver como es. Y cada uno que tiene tal esperanza en él se purifica como él es purificado'. Ese 'El' con cuya identidad el hombre en su futuro será igual, se refiere sin embargo en este lugar al llamado Padre en el Cielo, pero de hecho se refiere a partir de su igualdad esencial al Hijo del Hombre, como nuestra radicalización, identificación que sólo aparecería al final de la historia. Si se hubieran leído estos dos textos o si se los relacionara, entonces caería una luz, a la vez detectivesca y utópica, sobre el problema real de la alienación y sobre su posible superación. Eso significa de manera cristiana: lo que se había pensado bajo el nombre de Dios habría llegado a ser hombre por fin, y significa filosóficamente después y detrás de toda fenomenología hegeliana: la sustancia sería a la vez sujeto" ${ }^{38}$. Y Bloch añade: "El encuentro mencionado es curioso, pero ¿por qué no?"39. 


\section{NOTAS}

1. Me baso en el libro Gregorio Luri Medrano, Prometeo. Biografías de un mito, Trotta. Madrid, 2001, que de una manera nueva presenta la historia del mito de Prometeo.

2. En alemán, consciencia es "ser consciente". Marx insiste en eso varias veces. Dice por ejemplo: "La conciencia no puede ser nunca otra cosa que el ser consciente, y el ser de los hombres es un proceso de vida real.” en, Karl Marx y Friedrich Engels,, La ideología alemana, Montevideo, Pueblos Unidos, 1958, p. 25.

3. Richard, Pablo, "Teología en la teología de la liberación" en Mysterium Liberationis. Conceptos fundamentales de la Teología de liberación, Ellacuría, Ignacio y Sobrino, Jon (Eds), Trotta Madrid, 1990, I.tomo

4. Assmann, Hugo, La idolatría del mercado, DEI, San José (Costa Rica), 1997.

5. Antonio González reflexiona esta gran transformación, pero, como creo, no da suficiente importancia a este paso hacia la razón autónoma, que a partir del renacimiento asume este cambio: González, Antonio, Teología de la praxis evangélica. Ensayo de una teología fundamental, Sal Térrea, Santander, 1999.

6. “Acerba fata Romanos agunt, Scelusque fraternae necis”, Marx, Karl, El capital,. FCE. México, 1966, I, p. 606.

7. Ibid, p.50

8. Ibid, p. 423/424. He corregido la traducción según el texto original.

9. En Uruguay la cárcel principal en la cual se torturaban los presos políticos de la Dictadura de Seguridad Nacional se llamaba "La Libertad". En el campo de concentración de Guantánamo los militares de Estados Unidos tienen como santo y seña la frase "Honor bound to defend freedom" (El honor está comprometido para defender la libertad). El militar, que vigila dice: "Honor bound" y él que quiere entrar, contesta: "to defend freedom". Dicho eso, se abre el portón. [según Neue Zürcher Zeitung, Zürich, Suiza, 28.9.03 p.22] Los nazis escribieron sobre la entrada de sus campos de concentración: "Arbeit macht frei" [El trabajo hace libre]. El lenguaje neoliberal desemboca en el lenguaje del totalitarismo. De esta manera, revela lo que es. Esta libertad, de la cual Bush constantemente habla, es efectivamente una cárcel, una "jaula de acero". Eso es cierto en su doble sentido: todas las celdas de Guantánamo son construidas de puro acero.

10. Ver especialmente Dussel, Enrique, Ética de la liberación en la edad de la globalización y de la exclusión, Trotta. Madrid, 1998. Precisamente Dussel insiste en el carácter autónomo de esta ética expresada como ética de la liberación. En todas mis reflexiones presentes debo mucho a las discusiones largas y frecuentes con Enrique Dussel.

11. "Si el suicidio está permitido, todo está entonces permitido. Si algo no está permitido, entonces el suicidio no está permitido. Lo cual arroja una luz sobre la esencia de la ética. Porque el suicidio es, por así decirlo, el pecado elemental." Wittgenstein, Ludwig, Diario, 10.1.1917. Evidentemente, hay que matizar eso mucho más, pero indica un norte. Hoy, en Estados Unidos, el fundamentalismo cristiano expresa en términos míticos la disposición al suicidio colectivo de la humanidad. Está disfrazado por el lema de "Cristo viene". Por eso, expresa, que todo está permitido. Se comete el pecado que Wittgenstein llama "el pecado elemental".

12. Sobre el fundamentalismo ver Tamayo, Juan José, Fundamentalismos y diálogo entre religiones, Trotta. Madrid, 2004.

13. Sobre Karl Barth y la teología de liberación véase el análisis excelente de Plontz, Sabine, Die herrenlosen Gewalten. Eine Relektüre Larl Barths in befreiungstheologischer Perspektive. (Los poderes sin 
amos. Una relectura de Karl Barth desde la perspectiva de la teología de liberación), Grünewald. Mainz, 1995.

14. Ver también Hinkelammert, Franz J., "La crítica de la religión en nombre del cristianismo: Dietrich Bonhoeffer" en Teología alemana y teología latinoamericana de la liberación. Un esfuerzo de diálogo, DEI, San José, Costa Rica, 1990.

\section{RESÚMENES}

El mito de Prometeo, proveniente de la Grecia clásica, fue transformado desde fines de la Edad Media -especialmente a partir del Renacimiento-, en uno de los grandes mitos de la modernidad. Su importancia es tal que puede decirse que constituye el espacio mítico de todas las utopías de la modernidad desde la Utopía de Tomás Moro. Excede dichas utopías, y es su raíz mítica. Más aún: aparece también en los grandes pensamientos críticos de la modernidad burguesa, por eso, también contiene una clave para comprender el pensamiento utópico de Marx. Este mito moderno de Prometeo se vincula estrechamente con la crítica del cristianismo, que surge desde el Renacimiento y, a la vez sirve como trasfondo mítico en el surgimiento de nuevos enfoques de la ética. El texto destaca este papel clave del mito de Prometeo. Empieza analizando la forma que éste adquiere en el pensamiento de Marx, porque responde críticamente a las imaginaciones prometeicas anteriores.

Le mythe de Prométhée, provenant de la Grèce classique, a été transformé à partir de la fin du Moyen-âge - surtout à partir de la Renaissance - en un grand mythe de la modernité. Son importance est telle qu'il est possible d'affirmer qu'il constitue l'espace mythique de toutes les utopies de la modernité depuis l'Utopie de Tomas Moro. Il dépasse ces utopies, et constitue leur racine mythique. Plus encore : il apparaît aussi parmi les grandes réflexions critiques de la modernité bourgeoise, c'est pourquoi, il contient aussi une clef pour comprendre la pensée utopique de Marx. Ce mythe moderne de Prométhée est étroitement lié à la critique du christianisme, qui émerge dès la Renaissance et, sert à la fois de fond mythique dans l'émergence de nouvelles approches de l'éthique. Le texte souligne ce rôle clef du mythe de Prométhée. Il commence par une analyse de la forme qu'il acquiert dans la pensée de Marx, car il répond de manière critique aux imaginations prométhéiques antérieures.

The myth of Prometheus, which is originally a Greek myth, was transformed at the end of the Middle Ages, and especially since the Renaissance, and is one of the grand myths of modernity. Its importance is such that one can say it formulates the mythical space of all modern utopias from Thomas Moore until now. It underlies all modern myths, even when it is in itself a myth. Moreover, it appears in the great critical thoughts of the burgess modernity. For this reason it also contains a key to Marxist utopian thought. This modern myth of Prometheus is closely related to the criticism of Christianity as it appears ever since the Renaissance and at the same time serves as a mythical background for the upsurge of new focuses on ethics. In what follows we try to clarify this key role of the Promethean myth. We begin by analyzing the form this myth acquires in Marxist thought. We initiate this analysis with a Prometheus introduced by Marx because it responds critically to the previous Promethean images which are encountered. 
ÍNDICE

Palabras claves: Prometeo, modernidad, historia, sujeto

Mots-clés: Prométhée, modernité, histoire, sujet

Keywords: Prometheus, modernity, history, subject 